\title{
Semiquantitative Characterizations And Controlling Factors of Microscopic Pore Characteristics of The Metamorphic Rock Reservoir In The Central Paleo- Uplift Belt, Songliao Basin
}

\author{
Zhouqiang Zeng \\ Jilin University \\ Xuanlong Shan \\ Jilin University \\ Guoli Hao ( $\nabla$ haoguoli@jlu.edu.cn ) \\ Jilin University \\ Wentong He \\ Jilin University \\ Changqing Zheng \\ Jilin University \\ Jian Yi \\ Jilin University \\ Jiannan Guo \\ Jilin University
}

Research Article

Keywords: metamorphic, protoliths , microscopic , mylonite

Posted Date: June 23rd, 2021

DOI: https://doi.org/10.21203/rs.3.rs-618768/v1

License: (c) (1) This work is licensed under a Creative Commons Attribution 4.0 International License.

Read Full License 


\section{Abstract}

Currently, metamorphic rock is a common target for oil and gas exploration, and reservoirs are the key factors restricting hydrocarbon exploration and development in metamorphic rocks. The deep metamorphic rock gas reservoir in the central paleo-uplift of the northern Songliao Basin has good exploration and development potential. In this study, we use a combination of qualitative descriptions and quantitative analysis to comprehensively analyze the pore characteristics of the reservoir and explore the factors controlling the pore characteristics of the metamorphic rock reservoir in the central paleouplift belt of the Songliao Basin. The metamorphic rock reservoir in the central paleo-uplift belt contains three types of lithologies: chlorite schist, mylonite, and mica schist, each with different protoliths and metamorphic histories. The reservoir space can be divided into 4 pore types, and the reservoir space of each lithology is quite different. The results of high-pressure mercury intrusion and nitrogen adsorption indicate that the pore size distributions of the schist and mylonite differ. Compared with the schist, the mylonite has less reservoir space, stronger homogeneity, larger pore size, smaller specific surface area, more natural gas reservoir space and stronger natural gas adsorption capacity. This paper also studies the formation process of the reservoir and divides it into four stages. Finally, this article discusses in detail the factors controlling the microscopic pore characteristics of metamorphic rock reservoirs in the central paleo-uplift belt; the metamorphic rock protolith is the most important controlling factor.

\section{Introduction}

Currently, metamorphic rock is a common target for oil and gas exploration, and reservoir properties are the key factors restricting hydrocarbon exploration and development in metamorphic rocks ${ }^{1,2}$. It is now generally believed that the most important reservoir space in metamorphic rock reservoirs is fractures $3,4,5,6$. Therefore, through core observation and imaging logging, many scholars have finely characterized fractures, including the length, width, density, opening, dip of fractures, and the angle between ground stress and the strike of fractures (to judge whether the fracture is easy to open during fracturing), and have studied the formation, evolution stages and classification of fractures and whether there is fill and the nature of the fill $1,2,3,5,7,8,9$. At present, research on fractures in metamorphic rock reservoirs is relatively mature ${ }^{3,9}$. It is undeniable that fractures have a very important impact on the gas production of metamorphic rock reservoirs. However, in addition to fractures, there are many pores and microfissures that are invisible to the naked eye and cannot be identified by image logging in metamorphic rock reservoirs ${ }^{9,10}$. Similar to shale, these microscopic pores and microfissures can also become reservoir spaces and flow channels for natural gas, and fracturing technology makes production of natural gas from smaller pores possible ${ }^{11}$. Therefore, it is necessary to study the microscopic pores in metamorphic rock reservoirs. The combination of microscopic pores and macroscopic fractures can provide a more comprehensive understanding of the reservoir space in metamorphic rock reservoirs.

The pore characteristics of the metamorphic rock reservoir are relatively underexplored ${ }^{12,13}$. At present, research on metamorphic rock reservoirs is mainly based on fracture characterization and well logging 
identification, and there are few studies on the pore characteristics of metamorphic rock reservoirs and the factors that control them ${ }^{6,9}$.

Considerable controversy continues over the factors controlling the pore structure of metamorphic rock reservoirs. Xia et al. propose that the degree of metamorphism has a great impact on reservoir properties ${ }^{14}$, and Zhu et al. suggest that the lithology of metamorphic rocks is a core factor controlling reservoir formation and the preservation of reservoir space ${ }^{15}$. Han et al. suggest that the main factors controlling metamorphic reservoir development are temperature, lithology, minerals, dissolution, faults, and paleogeomorphology ${ }^{1}$. The research of Liu et al. has focused on rocks that have undergone contact metamorphism, and they conclude that the properties of metamorphic rocks are mainly controlled by lithology and diagenesis before intrusion ${ }^{16}$. Previous studies that have conducted research on reservoir pore characteristics have used mainly qualitative methods. In this study, we selected the cores of metamorphic rock reservoirs with underdeveloped macroscopic fractures using a combination of qualitative descriptions (thin section analysis, thin sections and scanning electron microscopy) and quantitative analysis (high-pressure mercury intrusion and nitrogen adsorption-desorption) to comprehensively analyze the pore characteristics of reservoirs and explore the factors controlling the pore characteristics of the metamorphic rock reservoir in the central paleo-uplift belt of the Songliao Basin in an attempt to provide ideas for improving the evaluation system of metamorphic rock gas reservoirs and provide guidance for the exploration of metamorphic rock gas reservoirs.

\section{Geological Setting}

The Songliao Basin is an important petroliferous basin in northeastern China that has three major structural sequences: a depression sequence, a faulted sequence, and the basement. A large number of oil fields, represented by the Daqing Changyuan superlarge oilfield, and a large number of natural gas fields, represented by the Xujiaweizi gas field, have been discovered in the depression sequence ${ }^{17,18}$. However, the exploration level of hydrocarbon resources in the basement of the Songliao Basin is still very low and is still in its infancy.

The investigated districts are located in the central paleo-uplift belt, which is located between the Xujiaweizi fault depression and the Gulong fault depression in the north (Fig. 1-a) and is a buried hill-like uplift zone formed on a basement containing thrust folds. The strata below the second member of the Denglouku Formation are absent above the basement, and the Denglouku Formation directly overlaps it.

In the three main salients in the central paleo-uplift belt, namely, the Wangjiatun salient, Zhaozhou salient and Changde salient, three risk wells were developed: the LT1, LT2 and LTX3 wells (Fig. 1-a). Among them, wells LT1 and LT2 reveal a metamorphic rock reservoir in the basement and have good natural gas shows. The daily gas production rate of the metamorphic rock reservoir in the LT1 well is $1.0 \times 10^{4} \mathrm{~m}^{3}$, and that of the LT2 well is $3.6 \times 10^{4} \mathrm{~m}^{3} 18$, which shows that the basement of the central paleo-uplift belt has 
good exploration potential and is an important strategic area for hydrocarbon resources in the Songliao Basin $^{19,20}$.

\section{Petrological Characteristics Of Metamorphic Rock Reservoir}

The lithologies revealed by the LT1 and LT2 wells are mainly metamorphic rocks. The basement revealed in the LT1 well can be divided into three lithological members: the lower member is mica schist, the middle member is mylonite, and the upper member is chlorite schist (Fig. 1-b). The basement revealed in the LT2 well can be divided into two lithological members: the lower member is mylonite, and the upper member is unmetamorphosed granite (Fig. 1-C). This article focuses only on metamorphic rocks. Two samples were taken from each lithological member. The specific information is shown in Table 1.

Table 1 Sample list

\begin{tabular}{|llllll|}
\hline Sample ID & Well & Depth $(\mathrm{m})$ & Lithology & Protolith & Metamorphism \\
\hline 1 & LT1 & 2778.67 & chlorite schist & andesite & dynamic \\
\hline 2 & LT1 & 2780.5 & chlorite schist & andesite & dynamic \\
\hline 3 & LT1 & 3374.44 & mica schist & clastic rock & regional \\
\hline 4 & LT1 & 3444.33 & mica schist & clastic rock & regional \\
\hline 5 & LT1 & 2986.97 & mylonite & granite & dynamic \\
\hline 6 & LT1 & 2989.77 & mylonite & granite & dynamic \\
\hline 7 & LT2 & 2961.7 & mylonite & granite & dynamic \\
\hline 8 & LT2 & 2964.4 & mylonite & granite & dynamic \\
\hline
\end{tabular}

\subsection{Chlorite schist}

The chlorite schist (Samples 1 and 2) in the LT1 well has a blasto-pilotaxitic texture (Fig. 2-a) and schistose structure (Fig. 2-b) and is mainly composed of quartz (approximately 15 vol.\%), feldspar (approximately $35 \mathrm{vol} . \%$ ), chlorite (approximately 35 vol.\%), biotite (approximately 5 vol.\%), epidote (approximately 5 vol.\%) and calcite. The minerals show directional alignment. Residual andesite phenocrysts and residual plagioclase can be observed (Fig. 2-b); albites have an ocellar structure (Fig. 2a). Therefore, the protolith of chlorite schist is andesite that experienced dynamic metamorphism.

\subsection{Mica schist}

The mica schist (Samples 3 and 4) in well LT1 has a porphyritic crystalloblastic texture, fine granular lepidoblastic texture and schistose structure and is mainly composed of quartz (approximately 25 vol.\%), feldspar (approximately 25 vol.\%), chlorite (approximately 12 vol.\%), mica (including biotite and muscovite, approximately 35 vol.\%) and garnet (approximately 3 vol.\%). Quartz and feldspar grains are 
separated by directionally aligned biotite and muscovite. Faint blastopsammitic structure (Fig. 2-d) can be observed. The abundance of micas implies that the rock contained mud, so the protolith was a clastic rock, and the metamorphism was regional.

\subsection{Mylonite}

The mylonite (Samples 5, 6, 7, and 8) in the LT1 and LT2 wells has a blastogranitic texture, deformation lamella and mica fish (Fig. 2-e) and is mainly composed of quartz (approximately 35 vol.\%), plagioclase (approximately $35 \mathrm{vol} . \%$ ), potash feldspar (approximately 25 vol.\%) and muscovite (approximately 2 vol.\%). Perthite porphyroclasts (Fig. 2-f) can be observed, and their edges consist of fine quartz that has been dynamically recrystallized and oriented, retaining the granitic structure of the protolith. The feldspar grains are subhedral, the quartz grains are allotriomorphic, and there are no signs of transport. In summary, the protolith was a granite, and the metamorphism was dynamic.

\section{Methods}

\subsection{Field emission scanning electron microscopy (FE-SEM)}

Field emission scanning electron microscopy (FE-SEM) experiments were carried out at the Test Science Experiment Centre of Jilin University. The microstructural morphology of the metamorphic rocks was observed using JSN-6700F equipment. The samples were cut into slices with a length and width of $1 \mathrm{~cm}$ and $1 \mathrm{~mm}$ thickness and subjected to ion polishing. All images were obtained under a high vacuum mode with an $8 \mathrm{kV}$ voltage. The working distance was approximately $10 \mathrm{~mm}$.

\subsection{High-pressure mercury intrusion (HPMI)}

High-pressure mercury intrusion (HPMI) experiments were conducted with a Micromeritics AutoPore IV 9520 system at the Beijing Centre for Physical and Chemical Analysis. The maximum intrusion pressure was 30000 psia (206.8 MPa), corresponding to a pore throat diameter of $6.6 \mathrm{~nm}$. The experimental process was as follows: samples were loaded into the core chamber and vacuum pumped for $1 \mathrm{~h}$. After mercury had filled the core chamber, measuring valves and balance valves were opened. Then, mercury was injected gradually under an applied pressure to measure the capillary pressure. Once a maximum pressure of 30000 psia was reached, the pressure started to decrease progressively, and mercury was extruded from the sample. Capillary pressure curves were derived by Micromeritics AutoPore IV 9520 software. The pore size distribution (PSD) was calculated according to the Washburn equation. The laboratory procedure followed Standard GB-T 21650.1-2008.

\subsection{Nitrogen adsorption-desorption experiments}

Nitrogen adsorption-desorption experiments were carried out at the Test Science Experiment Centre of Jilin University. Prior to adsorption measurements, all metamorphic rock samples were prepared by sieving to a size of 50-80 mesh and then weighing 2-6 g per sample. The samples were dried at $200^{\circ} \mathrm{C}$ for $6 \mathrm{~h}$ in a vacuum oven to remove moisture and volatile gases from the rocks. The Micromeritics 
ASAP2020 automatic device was used in the experiment, measuring the gas adsorption volume over the relative equilibrium adsorption pressure $\left(P / P_{0}\right)$ range of $0.01-0.99$, and the determinations of adsorption isotherms and outgassing were carried out in a liquid nitrogen environment.

\section{Results}

\subsection{Microscopic pore types and morphological characteristics}

Clay minerals can be identified by scanning electron microscopy. The chlorite schist contains many chlorites (Fig. 3-a), and the mica schist has the most types of clay minerals, including biotite, chlorite and a small amount of montmorillonite (Fig. 3-e), while mylonite has only a very small amount of chlorite.

Figure 3-c, 3-d and 3-h are all quartz particle surfaces. V-shaped holes can be observed in the chlorite schist, and the quartz particles are largely broken (Fig. 3-c), indicating that the chlorite schist formed mainly by mechanical effects during the process of rock formation. The mica schist has little evidence of mechanical effects during the process of rock formation, and although V-shaped holes can be seen (Fig. 3-f), the number of holes is small. Many scales are warped and separated from the carrier and have a tendency to spall (Fig. 3-d). Although these scales may also be debris formed in the grinding process of thin sections, their number is much greater than those in the chlorite schist (Fig. 3-C) and mylonite (Fig. 3h), and the scales are small; thus, they can be considered scaly spalling (a typical characteristic of chemical dissolution effects ${ }^{21}$ ). Irregular dissolution pits are also observed, so the mica schist was mainly chemically dissolved during the process of rock formation. The mylonite has obvious conchoidal fractures (Fig. 3-h); therefore, mechanical effects were clearly predominant during the process of rock formation.

Based on previous studies ${ }^{14,22}$ on the classification of metamorphic rock reservoir space and this study, the reservoir space of the metamorphic rock reservoir in the central paleo-uplift belt can be divided into the following four types: intergranular pores, dissolved pores, structural microfractures and weathering microfractures (Table 2). The main reservoir space in the chlorite schist is in the form of intergranular pores and weathering microfractures; the main reservoir space in the mica schist is in the form of intergranular pores and dissolved pores; and the main reservoir space in the mylonite is in the form of dissolved pores, weathering microfractures and structural microfractures.

Table 2 Types and characteristics of reservoir spaces in the metamorphic rock reservoir from the central paleo-uplift belt of the Songliao Basin. 


\begin{tabular}{|lll|}
\hline $\begin{array}{l}\text { Reservoir } \\
\text { space types }\end{array}$ & Origin & Characteristics \\
\hline $\begin{array}{l}\text { intergranular } \\
\text { pores }\end{array}$ & $\begin{array}{l}\text { primary intergranular pores in protolith } \\
\text { and pores formed among metamorphic } \\
\text { mineral }\end{array}$ & $\begin{array}{l}\text { angular, with a small pore size, visible } \\
\text { under a scanning electron } \\
\text { microscope }\end{array}$ \\
\hline $\begin{array}{l}\text { dissolved } \\
\text { pores }\end{array}$ & leaching, dissolution by formation fluid & $\begin{array}{l}\text { generally development along } \\
\text { fractures, irregular shape }\end{array}$ \\
\hline $\begin{array}{l}\text { structural } \\
\text { microfractures }\end{array}$ & $\begin{array}{l}\text { microfractures formed under tectonic } \\
\text { stress }\end{array}$ & irregular, extending far \\
\hline $\begin{array}{l}\text { weathering } \\
\text { microfractures }\end{array}$ & $\begin{array}{l}\text { formed by physical weathering and } \\
\text { breaking along the schistosity plane }\end{array}$ & $\begin{array}{l}\text { linear, funnel-shaped, developed in } \\
\text { schist }\end{array}$ \\
\hline
\end{tabular}

\subsection{Characteristics of high-pressure mercury porosity}

HPMI and nitrogen adsorption-desorption have proven to be effective methods for characterizing the pore structures of porous media ${ }^{23,24}$. The PSD that can be detected by HPMI is between $7.1 \mathrm{~nm}$ and $208 \mu \mathrm{m}$, and the PSD that can be detected by nitrogen adsorption is between $0.858 \mathrm{~nm}$ and $233.913 \mathrm{~nm}^{25}$. For the characterization of pore structures less than $200 \mathrm{~nm}$, nitrogen adsorption-desorption is more accurate than HPMI. Therefore, the HPMI method is used to characterize pores larger than $200 \mathrm{~nm}$, and the nitrogen adsorption method is used to characterize pores smaller than $200 \mathrm{~nm}^{26}$.

Figure 4 presents the high-pressure mercury capillary curves of schist and mylonite. The figure shows that the mercury entry curve changes from slow to steep, indicating more large pores and fewer small pores. The curve is generally linear, indicating poor pore sorting. The calculated mercury intrusion parameters are shown in Table 3. The average porosity of schist is $1.46 \%$, the average porosity of mylonite is $1.00 \%$, and the porosity of schist is higher than that of mylonite.

The displacement pressures of the metamorphic rock samples are very low. For the schist, the maximum value is $0.0643 \mathrm{MPa}$, and the average value is $0.0425 \mathrm{MPa}$. The maximum displacement pressure of the mylonite is only $0.0255 \mathrm{MPa}$, and the average is $0.0232 \mathrm{MPa}$ (Table 3), which is significantly less than that of the schist, indicating that the mylonite has a larger maximum pore throat and higher permeability ${ }^{27}$. The maximum mercury saturation can reflect the heterogeneity of the reservoir. The maximum mercury saturation of schist is $73.64 \%$ on average, while that of the mylonite is $84.32 \%$ on average (Table 3 ), reflecting that the schist is more heterogeneous and that mylonite is more homogeneous. The retreat mercury curves of the schist and mylonite are linear, and a large amount of mercury is withdrawn at the first point of pressure reduction. After this point, there is very little mercury withdrawal. The withdrawal efficiencies are very low, with values of $30.25 \%$ for the schist and $24.84 \%$ for the mylonite on average (Table 3).

Table 3 Parameters of high-pressure mercury intrusion for metamorphic rock samples 


\begin{tabular}{|lllll|}
\hline $\begin{array}{l}\text { Sample } \\
\text { ID }\end{array}$ & $\begin{array}{l}\text { Porosity } \\
(\%)\end{array}$ & $\begin{array}{l}\text { Displacement pressure } \\
(\mathrm{MPa})\end{array}$ & $\begin{array}{l}\text { Maximum pore throat } \\
(\mu \mathrm{m})\end{array}$ & $\begin{array}{l}\text { Withdrawal efficiency } \\
(\%)\end{array}$ \\
\hline 1 & 1.51 & 0.0643 & 19.40 & 11.25 \\
\hline 2 & 1.98 & 0.0275 & 45.32 & 7.68 \\
\hline 3 & 1.63 & 0.0370 & 33.72 & 6.43 \\
\hline 4 & 0.73 & 0.0412 & 29.77 & 43.28 \\
\hline Schist & 1.46 & 0.0425 & 32.05 & 17.16 \\
\hline Average & & & & 13.34 \\
\hline 5 & 1.28 & 0.0255 & 48.87 & 20.54 \\
\hline 6 & 1.07 & 0.0241 & 51.75 & 23.48 \\
\hline 7 & 0.91 & 0.0240 & 51.93 & 26.91 \\
\hline 8 & 0.73 & 0.0192 & 64.85 & 21.07 \\
\hline Mylonite & 1.00 & 0.0232 & 54.35 & \\
\hline Average & & & & \\
\hline
\end{tabular}

The pore distribution of metamorphic rock reservoir samples is shown in Fig. 5. It can be seen from the figure that the chlorite schist has the narrowest pore size distribution, the mylonite has a wider pore size distribution, and the mica schist has the widest pore size distribution. This shows that the heterogeneity of the mica schist is the strongest.

\subsection{Characteristics by nitrogen adsorption-desorption experiments}

Figure 6 presents the adsorption isotherms of the samples. When the relative pressure is very low, the nitrogen exhibits micropore filling and monolayer adsorption. As the relative pressure increases, the nitrogen molecules in the first layer reach saturation, and a relatively obvious inflection point appears in the isotherm adsorption curve (point B in Fig. 6, taking Sample 3 as an example, reflecting the existence of macropores and mesopores); then, multilayer adsorption occurs in the metamorphic rocks. As the relative pressure increases, the number of nitrogen molecule adsorption layers gradually increases. When the relative pressure rises to a certain value, the nitrogen gas in the pores starts to condense ${ }^{25}$. None of the samples show a horizontal plateau at a relative pressure close to 1 , illustrating that metamorphic samples still contain a range of macropores that cannot be analyzed by nitrogen adsorption-desorption experiments ${ }^{28}$. The adsorption quantity in the schist is much higher than that in the mylonite, indicating that the schist has more pore space than the mylonite.

The type of adsorption isotherm and the shape of the hysteresis loop can indicate the pore type of a porous medium ${ }^{26}$. According to the International Union of Pure and Applied Chemistry (IUPAC) 
classification, the schist has type II adsorption isotherms, and the mylonite has type III adsorption isotherms. The branch of the adsorption curve and the branch of the desorption curve do not coincide, forming a hysteresis loop that is caused by processes involving adsorption into and desorption from mesopores ${ }^{24}$. According to the IUPAC classification, the schist and mylonite have both H3-type loops and H4-type loops, indicating that the sample pore types are mainly flat, slit-like and ink bottle-shaped.

The results of nitrogen adsorption require the use of different data processing methods, such as the Brunauer-Emmett-Teller (BET) ${ }^{29,30}$, Barrett-Joyner-Hallenda (BJH) ${ }^{31}$ and density functional theory (DFT) models ${ }^{32}$. Nitrogen adsorption can yield three important parameters: specific surface area, average pore diameter and specific pore volume (Table 4). The BET method is suitable for calculating specific surface area, the BJH method is suitable for calculating average pore diameter, and the DFT method is suitable for calculating specific pore volume ${ }^{25}$. The specific pore volume of the schist is greater than that of the mylonite, which is consistent with the HPMI results. The specific surface area of the schist is also greater than that of the mylonite, while the average pore size is smaller than that of the mylonite.

Table 4 Nitrogen adsorption parameters of metamorphic rock samples

\begin{tabular}{|lllll|}
\hline $\begin{array}{l}\text { Sample } \\
\text { ID }\end{array}$ & Lithology & $\begin{array}{l}\text { Specific surface area } \\
\left(\mathrm{m}^{2} / \mathrm{g}\right)\end{array}$ & $\begin{array}{l}\text { Average pore diameter } \\
(\mathrm{nm})\end{array}$ & $\begin{array}{l}\text { Specific pore } \\
\text { volume }\left(\mathrm{cm}^{3} / \mathrm{g}\right)\end{array}$ \\
\hline 1 & schist & 4.3059 & 5.917 & 0.0085 \\
\hline 2 & schist & 1.6785 & 9.974 & 0.0049 \\
\hline 3 & schist & 2.8611 & 12.683 & 0.0074 \\
\hline 4 & schist & 0.8726 & 10.72 & 0.00271 \\
\hline $\begin{array}{l}\text { average value of } \\
\text { schist }\end{array}$ & 2.4295 & 9.824 & 0.00588 \\
\hline 5 & mylonite & 0.4557 & 30.635 & 0.0021 \\
\hline 6 & mylonite & 0.3062 & 45.375 & 0.00168 \\
\hline 7 & mylonite & 0.218 & 46.763 & 0.00024 \\
\hline 8 & mylonite & 0.781 & 45.626 & 0.00028 \\
\hline $\begin{array}{l}\text { average value of } \\
\text { mylonite }\end{array}$ & 0.4402 & 42.100 & 0.00108 \\
\hline
\end{tabular}

The BJH model cannot provide a realistic description of the filling of micropores or even smaller mesopores ${ }^{33}$, so we applied the DFT molecular model adsorption branch due to its applicability in determining the PSD at both the micropore (pore sizes $<2 \mathrm{~nm}$ ) and mesopore (pore sizes between $2 \mathrm{~nm}$ and $50 \mathrm{~nm}$ ) scales ${ }^{26,34}$. Figures 7 and 8 show the PSDs of the samples based on the DFT theory, clearly illustrating the PSD below $200 \mathrm{~nm}$, filling the gap of insufficient detection range and accuracy from HPMI. 
The PSD curve of the schist exhibits multimodal characteristics, with several maximum pore diameter values larger than $2 \mathrm{~nm}$ (Fig. 7). The mylonite has almost no pores smaller than $10 \mathrm{~nm}$, and its pores are mainly distributed between $50 \mathrm{~nm}$ and $200 \mathrm{~nm}$ (Fig. 8).

\section{Discussion}

\subsection{Pore fractal characteristics}

Fractal geometry has a strong ability to describe the irregular or fragmented shapes of natural features as well as other complex objects that traditional Euclidean geometry fails to characterize ${ }^{35}$. The fractal dimension (D) is the key parameter in fractal geometry and provides a systematic approach to quantifying irregular patterns ${ }^{36,37}$. The fractal Frenkel-Halsey-Hill (FHH) model has been proven to be the most effective method for analyzing the fractal behavior of porous media ${ }^{38}$. The $\mathrm{FHH}$ model, which has been widely recognized and used ${ }^{1,26,38,39}$, can be described using the following Eq. $3^{8}$ :

$$
\ln \frac{V}{V_{0}}=\text { constant }+(D-3) \ln \left(\ln \frac{P_{0}}{P}\right)
$$

where $\mathrm{V}$ is the quantity of adsorbed nitrogen gas at equilibrium pressure $\mathrm{P}, \mathrm{V}_{0}$ is the volume of monolayer coverage and $P_{0}$ is the saturation pressure.

According to the equation, on the plot of $\ln V$ vs $\ln \left(\ln \left(P_{0} / P\right)\right)$, the slope of the straight line should be equal to D-3. The FHH plots of metamorphic samples are shown in Fig. 8 and clearly show that the slopes of the $\mathrm{FHH}$ graphs of all samples are not uniform, so there is more than one fractal dimension. Based on previous studies $1,26,38,39$, the nitrogen adsorption isotherm can be divided into two main regions with a relative pressure of $0.5\left(P / P_{0}=0.5\right)$, obtaining two fractal dimensions, $D 1$ and $D 2$. Region 1 is the monolayer-multilayer adsorption in which the dominant force is van der Waals, and D1 can be calculated from the slope of the line in region 1 . Region 2 is the capillary condensation regime, where the surface tension is the dominant force, and D2 can be calculated from the slope of the line in region $2^{40,41}$. D1 represents fractals from pore surface areas generated by surface irregularities, while D2 characterizes fractals related to pore structures that are controlled by the composition and pore parameters. Higher fractal dimension D1 correlates to more irregular surfaces that provide more space for $\mathrm{CH}_{4}$ adsorption. Higher fractal dimension D2 represents higher heterogeneity of pore structure and higher liquid/gas surface tension that reduce $\mathrm{CH}_{4}$ adsorption capacity. The calculation results (Table 5) show obvious regularity. The D1 of the schist is lower than that of the mylonite; the average D1 of the schist is 2.1193, while the average D1 of the mylonite is 2.6782 , indicating that the mylonite has more irregular surfaces. The D2 of the schist is higher than that of the mylonite; the average D2 of the schist is 2.6643, while the average D2 of the mylonite is 2.4543 , indicating that schist has a higher pore heterogeneity of pore structure. The mylonite has a higher D1 and lower D2, indicating that it has more natural gas reservoir space and stronger natural gas adsorption capacity, making it a better reservoir. 
The U-Pb zircon dating results from our research team (Table 6) reveal that the concordant age of the chlorite schist is $131.3 \pm 8.5 \mathrm{Ma}$, indicating that the andesitic protolith formed during the deposition of the upper Shahezi Formation and lower Yingcheng Formation in the Cretaceous. The concordant age of unmylonitized granite in the upper part of the LT2 well is $160.7 \pm 1.9 \mathrm{Ma}$, which is Late Jurassic; the concordant age of granitic mylonite in the LT1 and LT2 wells is $264.2 \pm 2.6 \mathrm{Ma}$, indicating that the formation of the granitic protolith occurred in the middle-late Permian.

Table 5 Calculation results for fractal dimensions

\begin{tabular}{|llll|}
\hline Sample ID & Lithology & D1 & D2 \\
\hline 1 & schist & 1.5999 & 2.7665 \\
\hline 2 & schist & 2.2144 & 2.6488 \\
\hline 3 & schist & 2.3455 & 2.6015 \\
\hline 4 & schist & 2.3172 & 2.6403 \\
\hline average value of schist & 2.1193 & 2.6643 \\
\hline 5 & mylonite & 2.5595 & 2.4791 \\
\hline 6 & mylonite & 2.7089 & 2.4540 \\
\hline 7 & mylonite & 2.7316 & 2.4242 \\
\hline 8 & mylonite & 2.7489 & 2.4599 \\
\hline average value of mylonite & 2.6872 & 2.4543 \\
\hline
\end{tabular}

The concordant age of the the mica schist in Well LT1 is $275.2 \pm 2.6 \mathrm{Ma}$, indicating that the diagenesis of its clastic protolith occurred no earlier than 275.2 Ma (early Permian). Because the upper granite formed in the middle-late Permian, the formation of the clastic rock should have occurred earlier than the middlelate Permian, so the formation time of the clastic rock can be constrained to the early-middle Permian.

Table 6 Reservoir chronological results for the central paleo-uplift belt 


\begin{tabular}{|c|c|c|c|}
\hline Lithology & Protolith & Chronology & Formation time of the protolith \\
\hline $\begin{array}{l}\text { chlorite } \\
\text { schist }\end{array}$ & andesite & $\begin{array}{l}131.3 \pm 8.5 \\
\mathrm{Ma}\end{array}$ & $\begin{array}{l}\text { late Shahezi period-early Yingcheng period in } \\
\text { Cretaceous }\end{array}$ \\
\hline granite & & $\begin{array}{l}160.7 \pm 1.9 \\
\mathrm{Ma}\end{array}$ & Late Jurassic \\
\hline mylonite & granite & $\begin{array}{l}264.2 \pm 2.6 \\
\mathrm{Ma}\end{array}$ & middle-late Permian \\
\hline mica schist & $\begin{array}{l}\text { clastic } \\
\text { rock }\end{array}$ & $\begin{array}{l}275.2 \pm 2.6 \\
\mathrm{Ma}\end{array}$ & early-middle Permian \\
\hline
\end{tabular}

According to the structural background of the Songliao Basin and the four chronological test results, we hypothesize that the formation process of the metamorphic rock reservoir in the central paleo-uplift belt can be divided into the following four stages (Fig. 9):

(1) Formation and weathering of Permian protoliths

In the early-middle Permian, thick marine strata, i.e., the protoliths of the mica schist, were deposited (Fig. 9-a), and granitic magma then intruded in the middle-late Permian to form granite, forming the protolith of the mylonite. From the end of the Permian to the Early Triassic, the collision of the northeastern block and the North China Craton occurred along the Sauron-Siramulun-Changchun suture zone; this process uplifted the crust, and the strata underwent erosion (Fig. 9-b) ${ }^{42}$.

(2) Formation and weathering of Mesozoic protoliths

Previous studies have found Triassic strata in the Songliao Basin ${ }^{43}$. The Middle Triassic strata began to be deposited, and the Late Jurassic granitic magma later intruded (Fig. 9-c). In the Cretaceous period, when the Huoshiling Formation was deposited, during the low-angle subduction of the Pacific Plate towards the Asia-Europe Plate, basement faults became active ${ }^{44}$, and the Xuxi fault began to form (Fig. 9d) ${ }^{45}$. During the Cretaceous Huoshiling-Shahezi depositional period, weathering and erosion occurred. During the late Shahezi-early Yingcheng depositional period in the Cretaceous, lava erupted to form andesite, representing the protolith of the chlorite schist (Fig. 9-e).

(3) Metamorphic stage

The development of the basement reservoir in the central paleo-uplift zone of the Songliao Basin was related to the activity of the Xuxi fault ${ }^{20}$. Large-scale activity of the Xuxi fault occurred during the Shahezi-Yingcheng depositional period ${ }^{45}$, and the surrounding rocks were metamorphosed. Andesite in the upper part underwent both brittle deformation and ductile deformation under strong stress. At the same time, chlorite was produced by alteration of hornblende and formed the chlorite schist. The granite in the middle part also experienced brittle and ductile deformation but more ductile deformation. The clastic rocks in the lower part were buried deeper, and the increase in temperature triggered regional 
metamorphism. The mud was transformed into biotite, muscovite, garnet and chlorite, and the feldspar and quartz particles became directionally aligned, forming the mica schist. From shallow to deep, the degree of ductile deformation gradually increased, and the deep rock layer experienced regional metamorphism, which conforms to the behavior of dynamic metamorphic rock (fault rock) ${ }^{46}$. The Late Jurassic granite was not metamorphosed because it was far from the fault (Fig. 9-f).

(4) Weathering and deep burial

There is an unconformity between the Yingcheng Formation and Denglouku Formation in the Cretaceous, which is called the T4 unconformity surface. In the Yingcheng-Denglouku period, the strata underwent weathering and erosion. Because the Yingcheng Formation had a weak resistance to weathering and erosion, all of these rocks were removed. However, the chlorite schist is relatively resistant to weathering and erosion and was only partially removed, forming a weathering crust (Fig. 9-g). Subsequently, the overlying Cretaceous Denglouku Formation was deposited (Fig. 9-h).

6.3 Factors controlling microscopic pore characteristics of the metamorphic rock reservoir in the central paleo-uplift belt

(1) Effect of metamorphism on microscopic pore characteristics

(2) For andesite (the protolith of the chlorite schist), dynamic metamorphism can cause deformation and fracturing, increasing the reservoir space, while fine-grained chlorite is produced by alteration of hornblende and fills previously formed pores and fracture pores; thus, dynamic metamorphism has both constructive and destructive effects on the reservoir.

For granite (the protolith of the mylonite), dynamic metamorphism causes the originally dense granite to break and crack, having a constructive effect on the reservoir.

For clastic rocks (protoliths of the mica schist), regional metamorphism causes the minerals to recrystallize and directionally align, reducing the original pores and having destructive effects on the reservoir.

(3) Effect of structural location on microscopic pore characteristics

The influence of the structural position on microscopic pore characteristics is mainly reflected in the reservoir space derived from physical weathering. The chlorite schist and mylonite in the LT1 well and Late Jurassic granite in the LT2 well are weathered and eroded, so they all have weathering fractures, while the mica schist was below the surface, so no weathering fractures are observed.

(4) Effect of the protolith on microscopic pore characteristics

Many microscopic pore characteristics are related to the protolith characteristics. 
Andesite is formed by the eruption and rapid cooling of magma on the surface. Due to different volatiles, the vesicles in andesite are unevenly distributed, and phenocrysts are unevenly distributed in the matrix. The rock can also undergo varying degrees of weathering and leaching at the surface. Therefore, andesite is not homogeneous. Clastic rocks are formed by cementing various types of debris with different grain sizes; thus, they are also not homogeneous. In contrast, granite forms underground where the temperature is higher. The temperature decreases slowly, and it takes a long time for granite to crystalize, so it is relatively homogeneous. Judging from the results, both HPMI and fractal algorithms reveal that the schist is more heterogeneous than the mylonite.

The protoliths of the schist, whether andesite or clastic rock, were loose and porous, while the protolith of the mylonite was granite, which is very dense and basically nonporous. The HPMI experiments show that the schist has a higher porosity than the mylonite, and the nitrogen adsorption tests show that the adsorption quantity and specific pore volume of the schist are much higher than those of the mylonite. Although metamorphism reduced the pore space in the schist and increased the pore space in the granite, the original pore space of the protoliths largely controls the final pore space.

Generally, among the three kinds of protoliths, argillaceous siltstone has the most clay minerals, andesite has the second highest amount, and granite has the lowest amount of clay minerals. According to the SEM observations, the mica schist has the most clay minerals, including biotite, montmorillonite and chlorite. The chlorite schist contains a large amount of chlorite, and the mylonite contains only a very small amount of chlorite.

Quartz and feldspar are both brittle granular minerals that are prone to cracking under tectonic stress ${ }^{9}$, while dark-colored minerals are more elastic, have high ductility and are not prone to cracking ${ }^{10,15}$. Therefore, microfractures have developed in the mylonite, but microfractures cannot be found in the schist.

In addition, the protoliths controlled the metamorphic histories of the rocks to some extent. The granite in the middle part and the clastic rocks in the lower part are continuous vertically, and both formed in the Permian, but their metamorphic styles are different. The clastic rocks contain many impurities, such as matrix material, mica and chlorite debris, which are prone to alteration. In contrast, the granite mineral composition is basically quartz and feldspar, which are simple, relatively stable and not prone to alteration. Temperature was the dominant factor in the metamorphism of the schist, which overall experienced regional metamorphism, while stress was the dominant factor in the metamorphism of the mylonite and caused partial dynamic metamorphism.

In summary, the microscopic pore characteristics of the metamorphic rock reservoir are controlled by the metamorphic style, structural location and protolith, among which the protolith was the most important controlling factor.

\section{Conclusions}


1. Three metamorphic rock reservoir lithologies are revealed in wells LT1 and LT2: the chlorite schist formed by dynamic metamorphism from an andesitic protolith; the mylonite formed by dynamic metamorphism from a granitic protolith; and the mica schist formed by regional metamorphism from clastic protoliths.

2. The reservoir space can be divided into four types: intergranular pores, dissolved pores, structural microfractures and weathering microfractures.

3. The PSDs of the schist and mylonite are different.

4. Compared with the schist, the mylonite has less reservoir space, stronger homogeneity, larger pore size, smaller specific surface area, more natural gas reservoir space and stronger natural gas adsorption capacity.

5. The formation process of the reservoir can be divided into four stages: formation and weathering of Permian protoliths, formation and weathering of Mesozoic protoliths, metamorphism and weathering and deep burial.

6. The microscopic pore characteristics of the metamorphic rock reservoir are controlled by the metamorphic style, structural location and protolith, among which the protolith is the most important controlling factor.

\section{References}

1. Agnes, F., Varga-Toth, l., Toth, T., 2014. Lithology identification using open-hole welllog data in the metamorphic kiskunhalasne hydrocarbon reservoir, south Hungary. Acta Geodaetica Et Geophysica 49 (1), 57-78.

2. Avnir, D.; Jaroniec, M. An isotherm equation for adsorption on fractal surfaces of heterogeneous porous materials. LANGMUIR. 1989, 5, 1431-1433.

3. Bai, X.; Liang, J.; Zhang, W.; Fu, L.; Peng J.; Xue T.; Yang L.; Liu, J. Geologic conditions, resource potential and exploratory direction of deep gas in the northern Songliao Basin. Natural Gas Geoscience. $2018,29,1443-1454$.

4. Barrett, E. P.; Joyner, L. G.; Halenda, P. P. The Determination of Pore Volume and Area Distributions in Porous Substances. I. Computations from Nitrogen Isotherms. J AM CHEM SOC. 1951, 73, 373-380.

5. Brunauer, S.; Emmett, P. H.; Teller, E. Adsorption of Gases in Multimolecular Layers. J AM CHEM SOC. $1938,60,309-319$.

6. Cai, Y.; Liu, D.; Yao, Y.; Li, J.; Liu, J. Fractal Characteristics of Coal Pores Based on Classic Geometry and Thermodynamics Models. Acta Geologica Sinica. 2011, 85, 1150-1162. 
7. Cao, Z.; Liu, G.; Zhan, H.; Li, C.; You, Y.; Yang, C.; Jiang, H. Pore structure characterization of Chang-7 tight sandstone using MICP combined with N2 GA techniques and its geological control factors. SCI REPUK. 2016, 6, 36919.

8. Diduszko, R.; Swiatkowski, A.; Trznadel, B. J. On surface of micropores and fractal dimension of activated carbon determined on the basis of adsorption and SAXS investigations. CARBON. 2000, 38 , $1153-1162$.

9. Do, D. D.; Do, H. D. Pore Characterization of Carbonaceous Materials by DFT and GCMC Simulations: A Review. ADSORPT SCI TECHNOL. 2003, 21, 389-423.

10. Du, T.; Shan, X.; Yi, J.; Qu, Y. Quantitative Characteristics of Nanoscale Pores in Gas-Bearing Volcanic Rocks of the Yingcheng Formation in the Songnan Gas Field. Energy\&Fuel. 2017, 31, 10655-10664.

11. Du, J. Analysis of natural gas accumulation conditions and exploration perspective in the central paleo-uplift belt (north), Songliao Basin. China Petroleum Exploration. 2017, 22, 1-14.

12. Endo, A.; Suzuki, N.; Komori, A.; Kimura, Y.; Utsugi, H. Three parametric equations and their adaptability. (III). The adaptation of a three parameter adsorption equation to the adsorption isothems of carbon black with a micropore. Journal of the Society of Powder Technology. 1989, Japan, 26, 85-92.

13. Gao, S.; Hu, Z.; Liu, H.; Ye, Y.; An, W. Microscopic pore characteristics of different lithological reservoirs. Acta Petrolei Sinca. 2016, 37, 248-256.

14. Han, C.; Tian, J.; Hu, C.; Liu, H.; Wang, W.; Huan, Z.; Feng, S. Lithofacies characteristics and their controlling effects on reservoirs in buried hills of metamorphic rocks: A case study of late Paleozoic units in the Aryskum depression, South Turgay Basin, Kazakhstan. Journal of Petroleum Science and Engineering. 2020,191,107-137.

15. Han, J. Study on the effect of synergy of water and oxygen on pyrolysis characteristics of oil shale, Jilin University. 2019, pp. 142.

16. Khalili, N. R.; Pan, M.; Sandí, G. Determination of fractal dimensions of solid carbons from gas and liquid phase adsorption isotherms. CARBON. 2000, 38, 573-588.

17. Kostoglou, N.; Constantinides, G.; Charalambopoulou, G.; Steriotis, T.; Polychronopoulou, K.; Li, Y.; Liao, K.; Ryzhkov, V.; Mitterer, C.; Rebholz, C. Nanoporous spongy graphene: Potential applications for hydrogen adsorption and selective gas separation. THIN SOLID FILMS. 2015, 596, 242-249.

18. Lee, G.; Pyun, S. The effect of pore structures on fractal characteristics of meso/macroporous carbons synthesised using silica template. CARBON. 2005, 43, 1804-1808.

19. Liang, Z.; Cai, Z.; Wang, Z.; Li, C. Relationship between Xuxi Discordogenic Fault and Volcanic Reservoir Formation. Xushen Area, Natural Gas Geoscience. 2009, 20, 372-377. 
20. Li. C. Application of Scanning Electron Microscope in Geology. Petroleum Industry Press, Beijing, 1990.

21. Liu, C.; Xie, Q.; Wang, G.; Zhang, C.; Wang, L.; Qi, K. Reservoir properties and controlling factors of contact metamorphic zones of the diabase in the northern slope of the Gaoyou Sag, Subei Basin, eastern China. Scientific Reports. 2016, 35, 392-411.

22. Liu, G.; Zeng, L.; Li, H.; Ostadhassan, M.; Rabiei, M. Natural fractures in metamorphic basement reservoirs in the Liaohe Basin,China. Mar. Petrol. Geol. 2020,119,104479.

23. Liu, K.; Ostadhassan, M.; Zhou, J.; Gentzis, T.; Rezaee, R. Nanoscale pore structure characterization of the Bakken shale in the USA. FUEL. 2017, 209, 567-578.

24. Lopes, R.; Betrouni, N. Fractal and multifractal analysis: A review. MED IMAGE ANAL. 2009, 13, 634649 .

25. Li, X. Characteristics of Bedrock Reservoirs in the Eastern Segment of Altun Piedmont. China University of Petroleum, Beijing. 2019. pp. 27.

26. Mandelbrot, B. B. The fractal geometry of nature, W.H. Freeman. New York, 1983.

27. Milewska-Duda, J.; Duda, J. T. New BET-like models for heterogeneous adsorption in microporous adsorbents. APPL SURF SCI. 2002, 196, 115-125.

28. Molnár, L.; Vásárhelyi, B.; Tóth, T.; Schubert, F. Integrated petrographic - rock mechanic borecore study from the metamorphic basement of the Pannonian Basin, Hungary. Open Geosci. 2015; 7:53-64.

29. Nagy, Á.; Tóth, T. M.; Vásárhelyi, B.; Földes, T. Integrated core study of a fractured metamorphic HCreservoir; Kiskunhalas-NE, Pannonian Basin. ACTA GEOD GEOPHYS. 2013, 48, 53-75.

30. Neimark, A.V.; Lin, Y.; Ravikovitch, P. I.; Thommes, M. Quenched solid density functional theory and pore size analysis of micro-mesoporous carbons. CARBON. 2009, 47, 1617-1628.

31. Qi, H.; Ma, J.; Wong, P. Adsorption isotherms of fractal surfaces. Colloids and Surfaces A. 2002, 206, 401-407.

32. Ravikovitch, P. I.; Haller, G. L.; Neimark, A.V. Density functional theory model for calculating pore size distributions: pore structure of nanoporous catalysts. ADV COLLOID INTERFAC. 1998, 76, 203-226.

33. Ravikovitch, P. I.; Vishnyakov, A.; Russo, R.; Neimark, A. V. Unified Approach to Pore Size Characterization of Microporous Carbonaceous Materials from $\mathrm{N}_{2}$, $\mathrm{Ar}$, and $\mathrm{CO}_{2}$ Adsorption Isotherms. LANGMUIR. 2000, 16, 2311-2320. 
34. Ravikovitch, P. I.; Neimark, A. V. Density Functional Theory Model of Adsorption on Amorphous and Microporous Silica Materials. LANGMUIR. 2006, 22, 11171-11179.

35. Schmitt, M.; Fernandes, C. P.; Da Cunha Neto, J. A. B.; Wolf, F. G.; Dos Santos, V. S. S. Characterization of pore systems in seal rocks using Nitrogen Gas Adsorption combined with Mercury Injection Capillary Pressure techniques. Marine and Petroleum Geology. 2013, 39, 138-149.

36. Sun, C. The research of the basement tectonic characteristics of Songliao basin based on geophysical methods. Jilin University. 2019, pp. 66.

37. Tóth, T.; Tóth, I. Lithologically controlled behaviour of the Dorozsma metamorphic hydrocarbon reservoir (Pannonian Basin, SE Hungary). . Int. J. Petrol. Sci. Technol. 2020, 195, 107748.

38. Tong, K.; Zhao, C.; Liu, Z.; Zhang, Y.; Zheng, H.; Xu, S.; Wang, J.; Pan, L. Reservoir evaluation and fracture chracterization of the metamorphic buried hill reservoir in Bohai Bay Basin. Petroleum Exploration and Development Online. 2012, 39, 62-69.

39. Tong, K.; Li, B.; Dai, W.; Zheng, H.; Zhang, Z.; Cheng, Q.; Wang, J.; Fang, N. Sparse well pattern and high-efficient development of metamorphic buried hills reservoirs in Bohai Sea area, China. Petroleum Exploration and Development. 2017, 44, 625-635.

40. Wang, D.; Wang, Q.; Liu, X.; Zhao, M.; Hao, Y. Characteristics and developing patterns of gneiss buried hill weathering crust reservoir in the sea area of the Bohai Bay basin. Acta Petrologica Sinica. 2019, 35, 1181-1193.

41. Wang, S. Research of structural feature and basin-forming synamic in the north of Songliao basin. Chengdu University of Technology. 2013, pp. 152.

42. Wu, S.; Zhai, X.; Yang, Z.; Bale, H.; Hong, Y.; Cui, J.; Pan, S.; Lin, S. Characterization of fracture formation in organic-rich shales - An experimental and real time study of the Permian Lucaogou Formation, Junggar Basin, northwestern China. Marine and Petroleum Geology. 2019, 107, 138-149.

43. Wu, Z.; Guo, J.; Wu, D. Fractured characterstics of metamorphic reservoirs in low buried-hill in west of Jinganpu, Damintun depression. Oil\&Gas Geology. 2001, 322-325.

44. Xia, Z.; Liu, Z.; Li, S.; Zhang, Y.; Wang, B.; Tian, M.; Wu, J.; Zou, K. Characteristics of parametamorphic rock reservoirs in Pingxi area. Qaidam Basin, NW China, Petroleum Exploration and Development Online. 2019, 46, 93-103.

45. Xoaotb, B. Coal and Gas Outburst. Song, S.; Wang, Y. Translation. Beijing: China Industry Press, 1966. 46. Yang, F.; Ning, Z.; Kong, D.; Liu, H. Pore structure of shales from high pressure mercury injection and nitrogen adsorption method. Natural Gas Geoscience. 2013, 24, 450-455. 
47. Yao, Y.; Liu, D.; Tang, D.; Tang, S.; Huang, W. Fractal characterization of adsorption-pores of coals from North China: An investigation on CH4 adsorption capacity of coals. INT J COAL GEOL. 2008, 73, 27-42.

48. Ye, T.; Wei, A.; Sun, Z.; Gao, K.; Cheng, Q. The reservoir characteristics and their significance for deliverability in metamorphic granite buried hill: a case study from the JZS oil field in the Liaodong Bay Basin, NE China. Arabian Journal of Geosciences (2019) 12: 630.

49. Yin, Y.; Gao, Y.; Wang, P.; Qu, X.; Liu, H. Discovery of Triassic volcanic-sedimentary strata in the basement of Songliao Basin. SCI BULL. 2019, 64, 644-646.

50. Yi, S.; Li M.; Xu S et al. Accumulation condition and model of buried hill in the Central Uplift $\$ Songliao Basin, Natural Gas Geoscience. 2020, 31(12), 1663-1676.

51. You, Z. Metamorphic rock petrology course. China University of Geosciences Press, 1988.

52. Yu, Z.; Du, Y.; Xiao, K.; Wang, J et al. Characteristics and influence factors of basement buried- hill reservoir in Bongor Basin,Chad. Acta Petrologica Sinica, 35(4):1279-1290

53. Zhang, J.; Liu, G.; Torsaeter, O.; Tao, S.; Jiang, M.; Li, G.; Zhang, S. Pore-throat structure characteristics and its effect on flow behavior in Gaotaizi tight siltstone reservoir, northern Songliao Basin. Mar. Petrol. Geol. 2020, 122, 104651.

54. Zhang, W. The coupling relationship of crust-mantle scale faults with the faults of upper construction in deep of Songliao basin. Northeast Petroleum University , 2011, pp. 57.

55. Zhao, L.; Guanhua, N.; Lulu, S.; Qian, S.; Shang, L.; Kai, D.; Jingna, X.; Gang, W. Effect of ionic liquid treatment on pore structure and fractal characteristics of low rank coal. FUEL. 2020, 262, 116513.

56. Zhu, Y.; Shan, J.; Wang, H.; Cai, G. Petrological characteristics of Archean metamorphic reservoir in central area of Damintun depression, Liaohe. Journal of Jilin University (Earth Science Edition). 2018, 48, 1304-1315.

57. Zhu, Z. Metamorphic rock reservoir logging evaluation method of effectiveness research. Yangtze University, 2013, pp. 61.

58. Zhou, J.; Wilde, S. A.; Zhao, G.; Han, J. Nature and assembly of microcontinental blocks within the Paleo-Asian Ocean. EARTH-SCI REV. 2018, 186, 76-93.

\section{Figures}




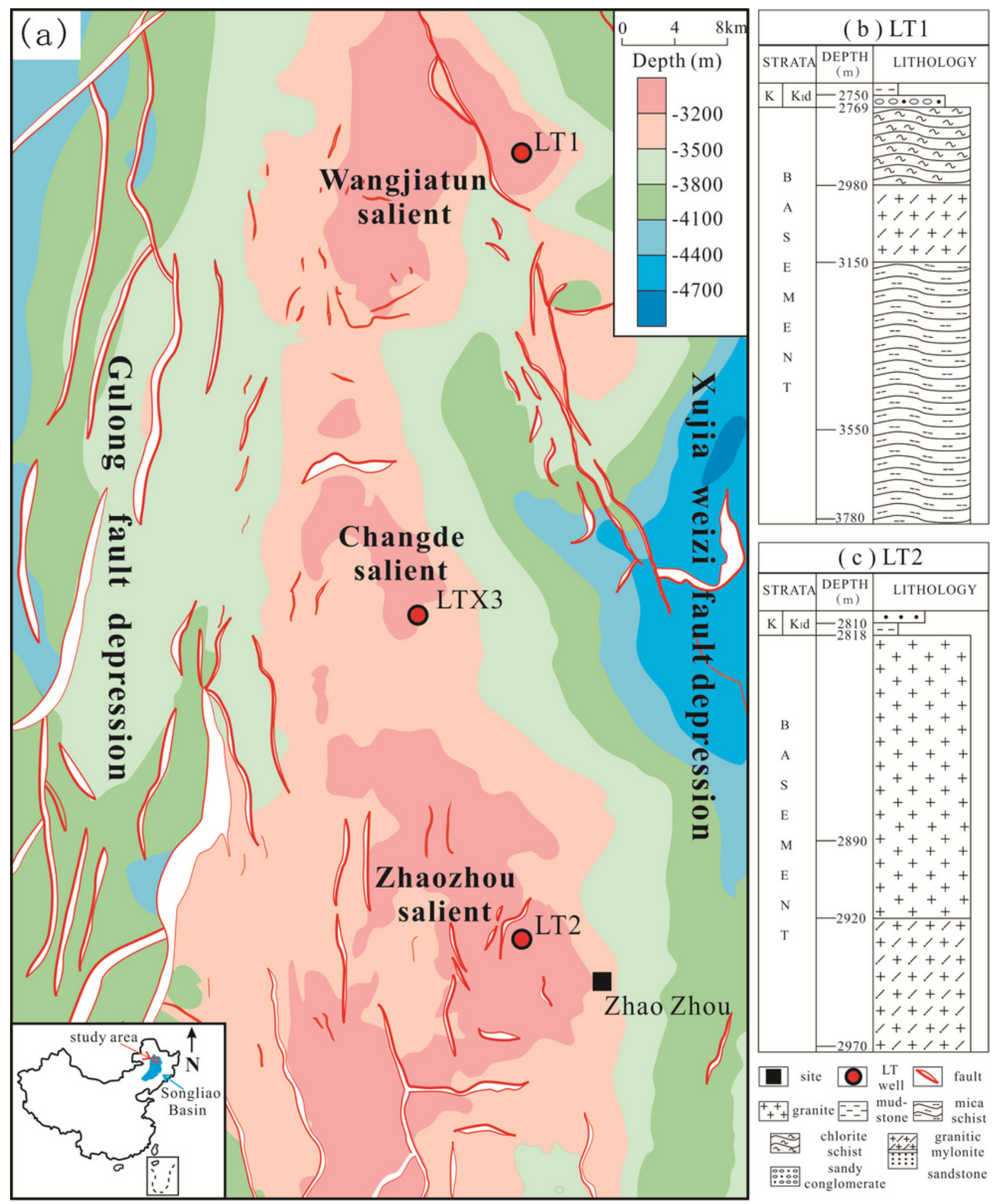

\section{Figure 1}

(a) Structural map of the top of the basement in the central paleo-uplift zone and the distribution of well locations (modified from Du et al., 20171); (b) basement stratigraphic column of the LT1 well; (c) basement stratigraphic column of the LT2 well. Note: The designations employed and the presentation of the material on this map do not imply the expression of any opinion whatsoever on the part of Research 
Square concerning the legal status of any country, territory, city or area or of its authorities, or concerning the delimitation of its frontiers or boundaries. This map has been provided by the authors.
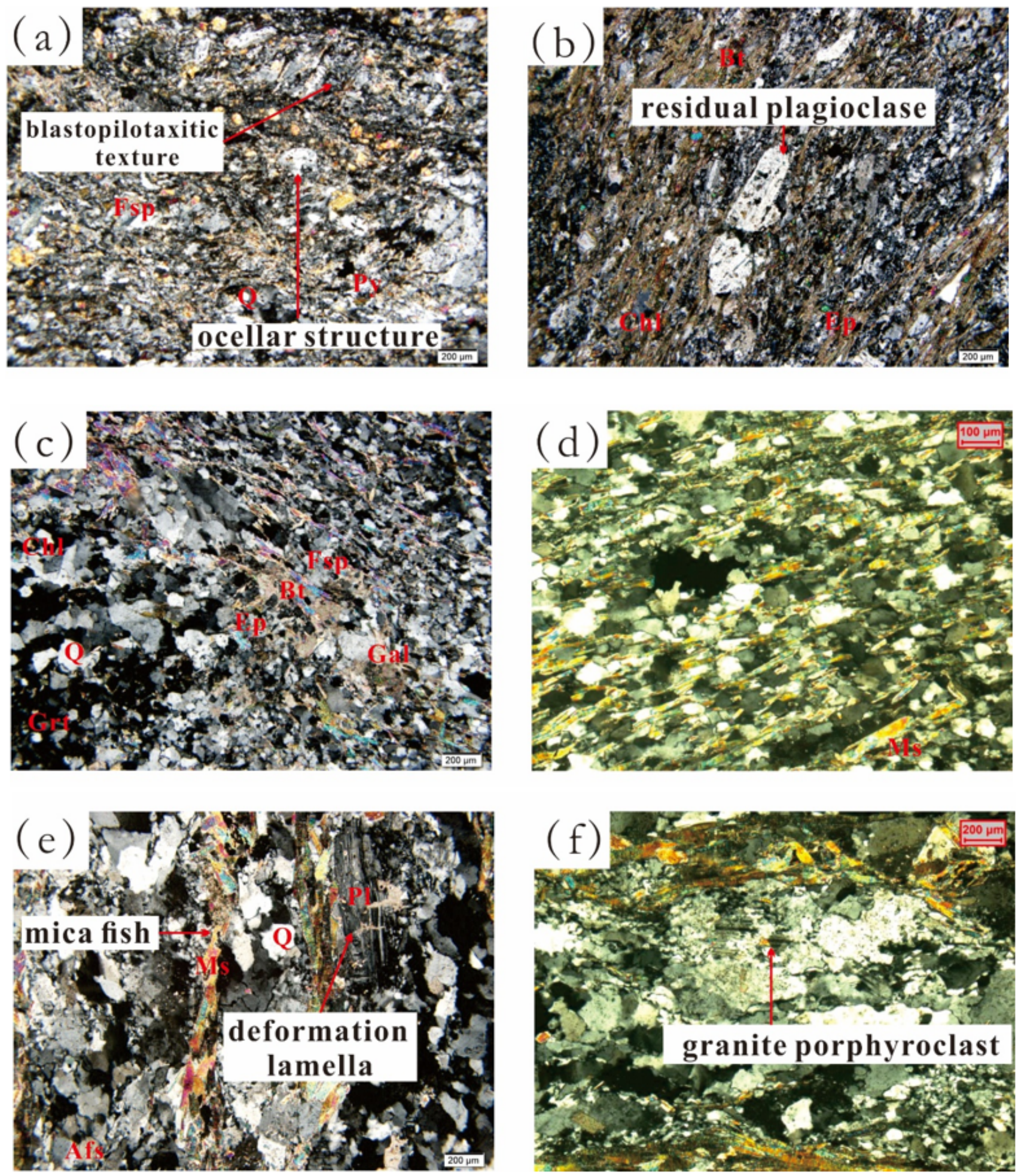

Figure 2

Photomicrographs showing the petrological characteristics of the metamorphic rock reservoir: (a) sample 1, chlorite schist (-); (b) sample 1, sample 2, chlorite schist (+); (c) sample 4, mica schist (+); (d) sample 3, mica schist (-); (e) sample 5, mylonite (+); (f) sample 7, mylonite (+) Note: The designations employed 
and the presentation of the material on this map do not imply the expression of any opinion whatsoever on the part of Research Square concerning the legal status of any country, territory, city or area or of its authorities, or concerning the delimitation of its frontiers or boundaries. This map has been provided by the authors.
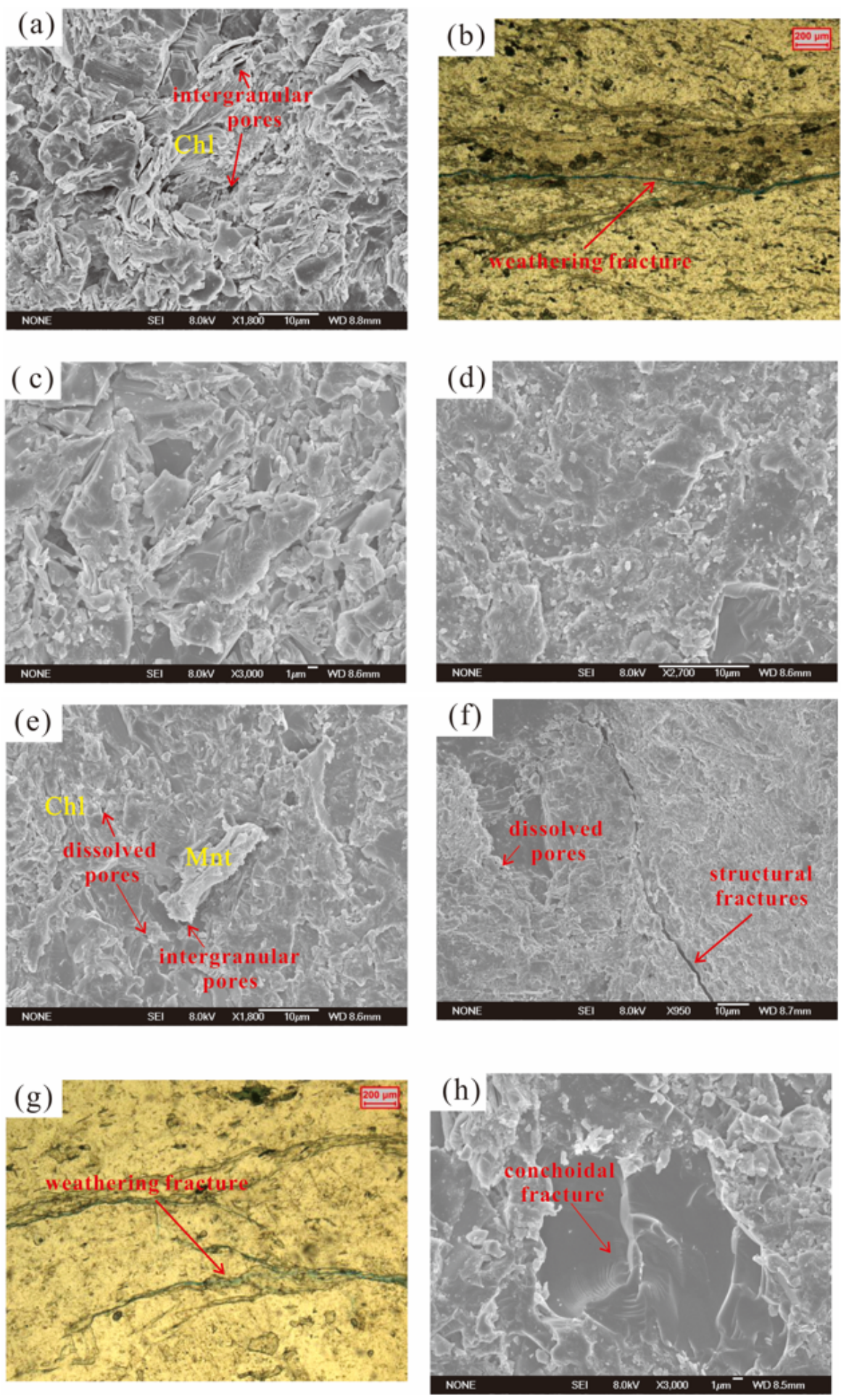

\section{Figure 3}


Types of reservoir space in metamorphic rock samples. (a) chlorite schist, 1; (b) chlorite schist, 2; (c) chlorite schist, 2, with quartz surface; (d) mica schist, 5, with quartz surface; (e) mica schist, 5; (f) mylonite, 6; (g) mylonite, 5; (h) mylonite, 7, with quartz surface. Note: The designations employed and the presentation of the material on this map do not imply the expression of any opinion whatsoever on the part of Research Square concerning the legal status of any country, territory, city or area or of its authorities, or concerning the delimitation of its frontiers or boundaries. This map has been provided by the authors.

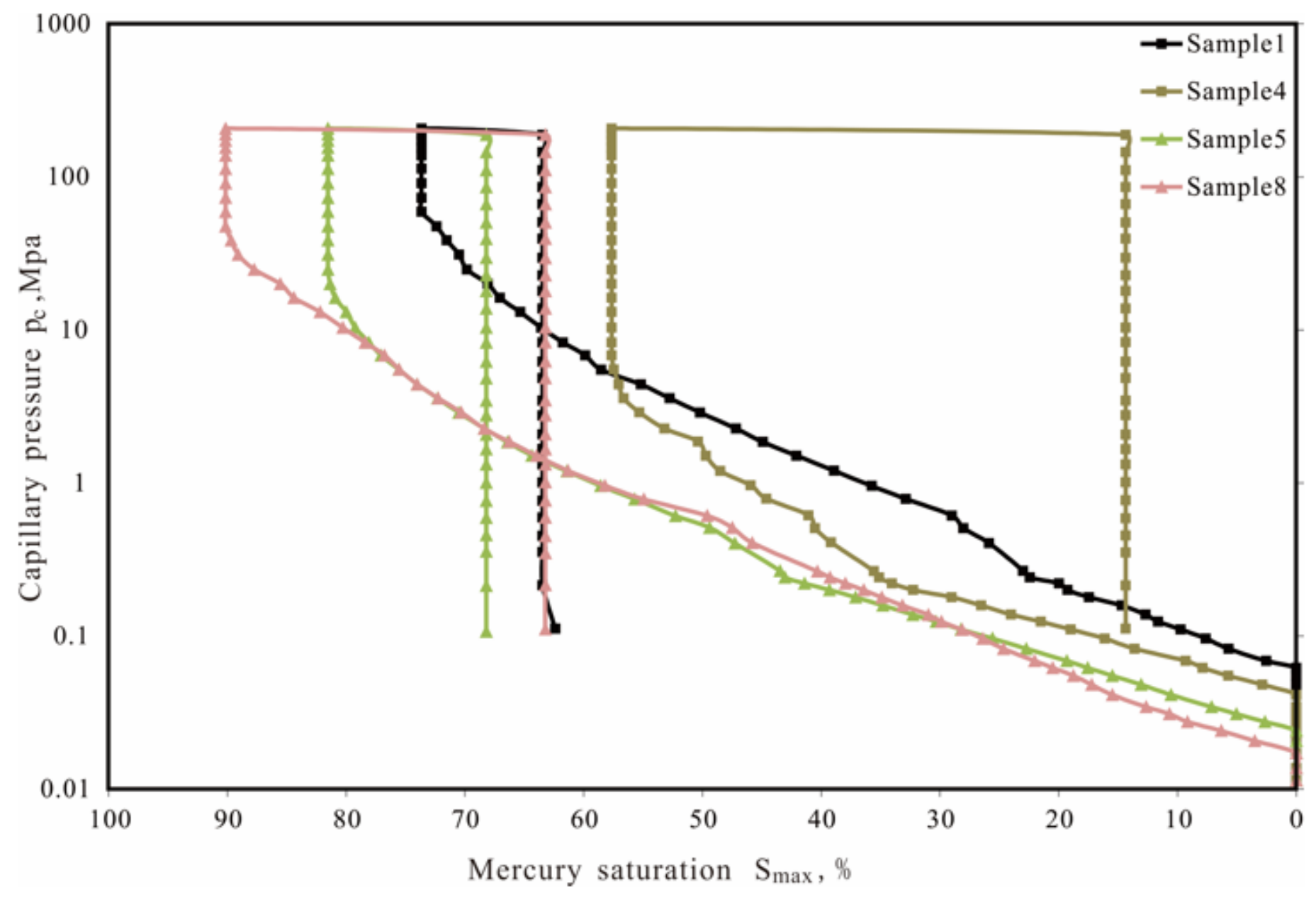

Figure 4

Capillary pressure curve of the metamorphic rock reservoir sample. 

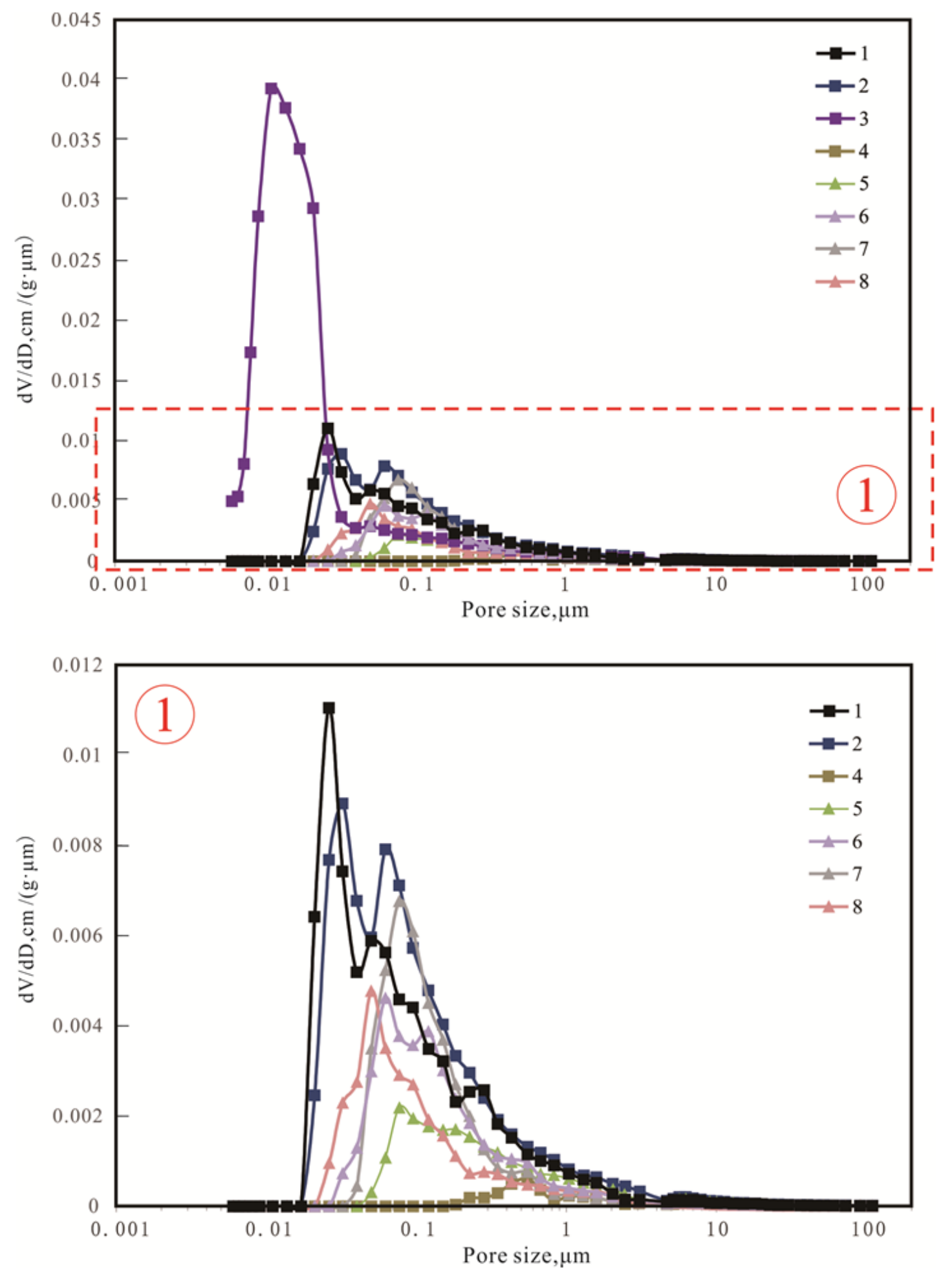

Figure 5

Pore distributions of metamorphic rock reservoir samples through high-pressure mercury injection. 

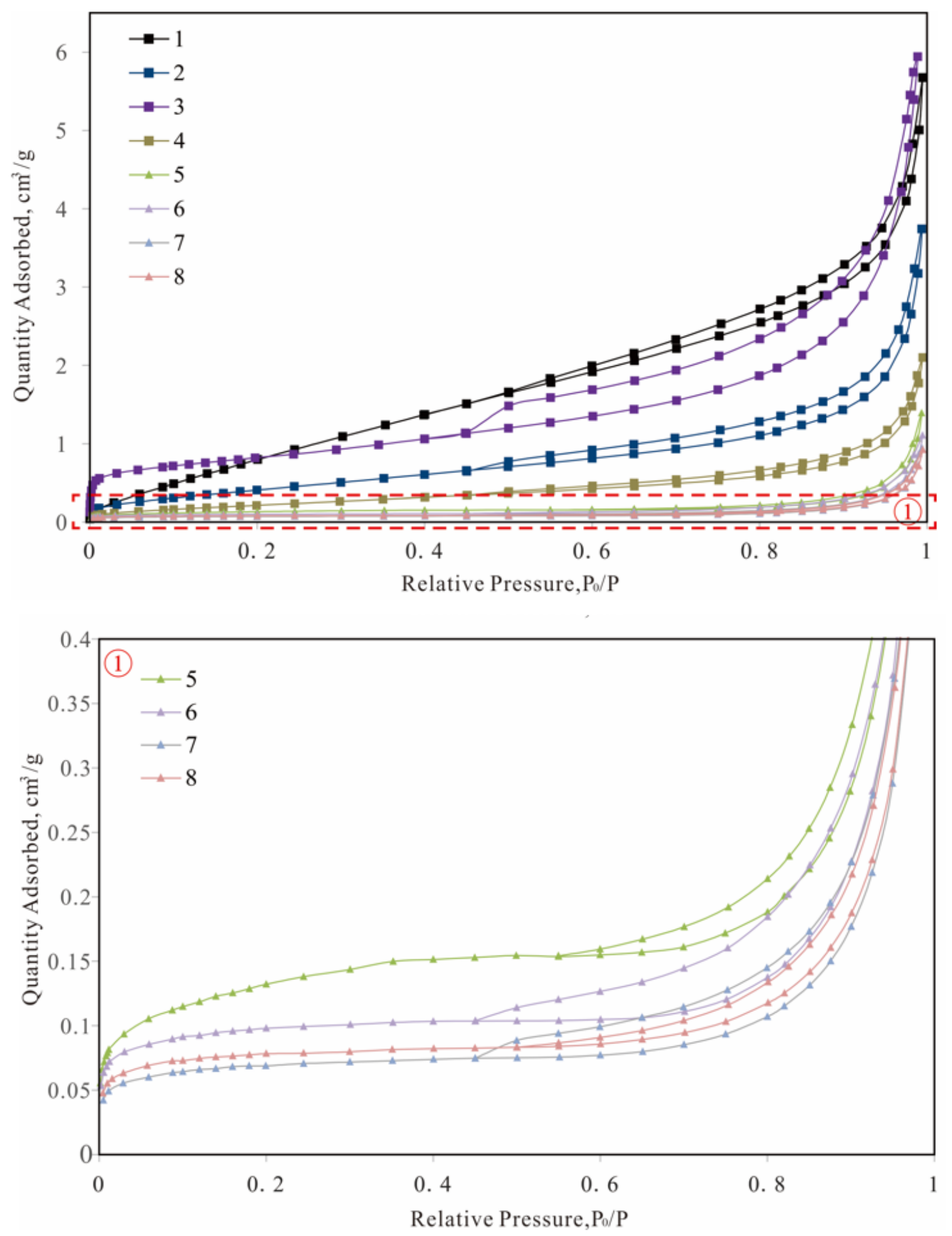

Figure 6

N2 gas adsorption/desorption isotherms. 

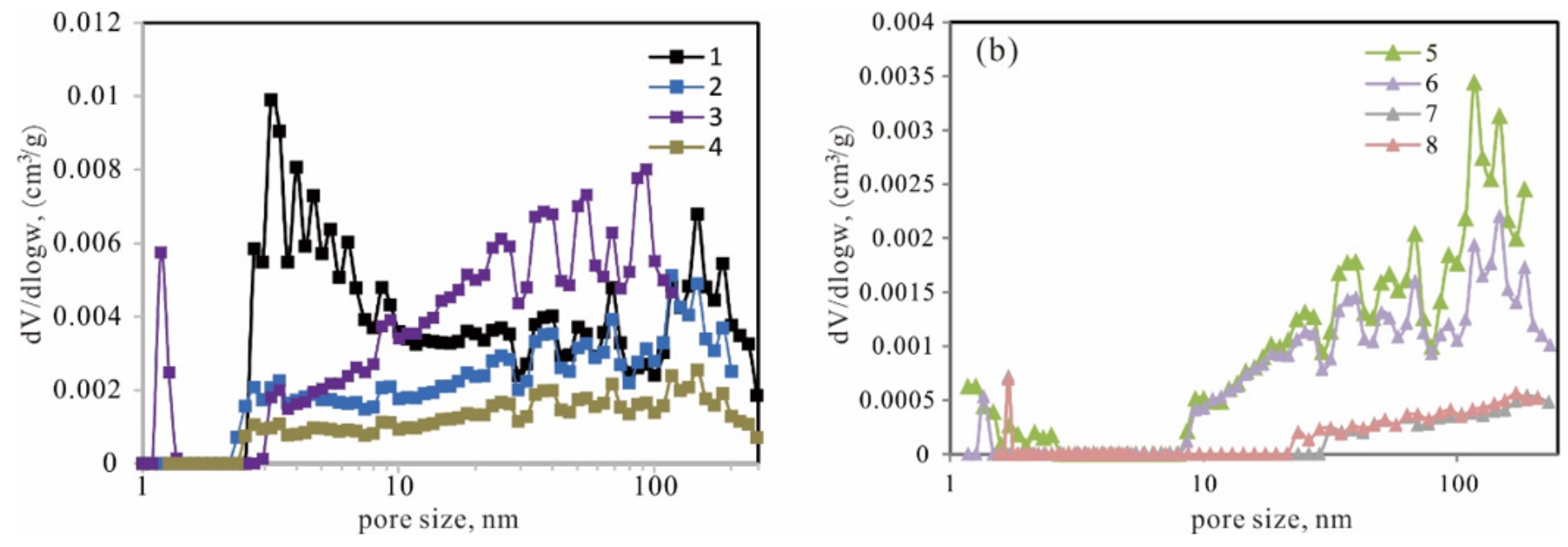

Figure 7

(a) PSD analysis of schist samples using DFT methods; (b) PSD analysis of mylonite samples using DFT methods 

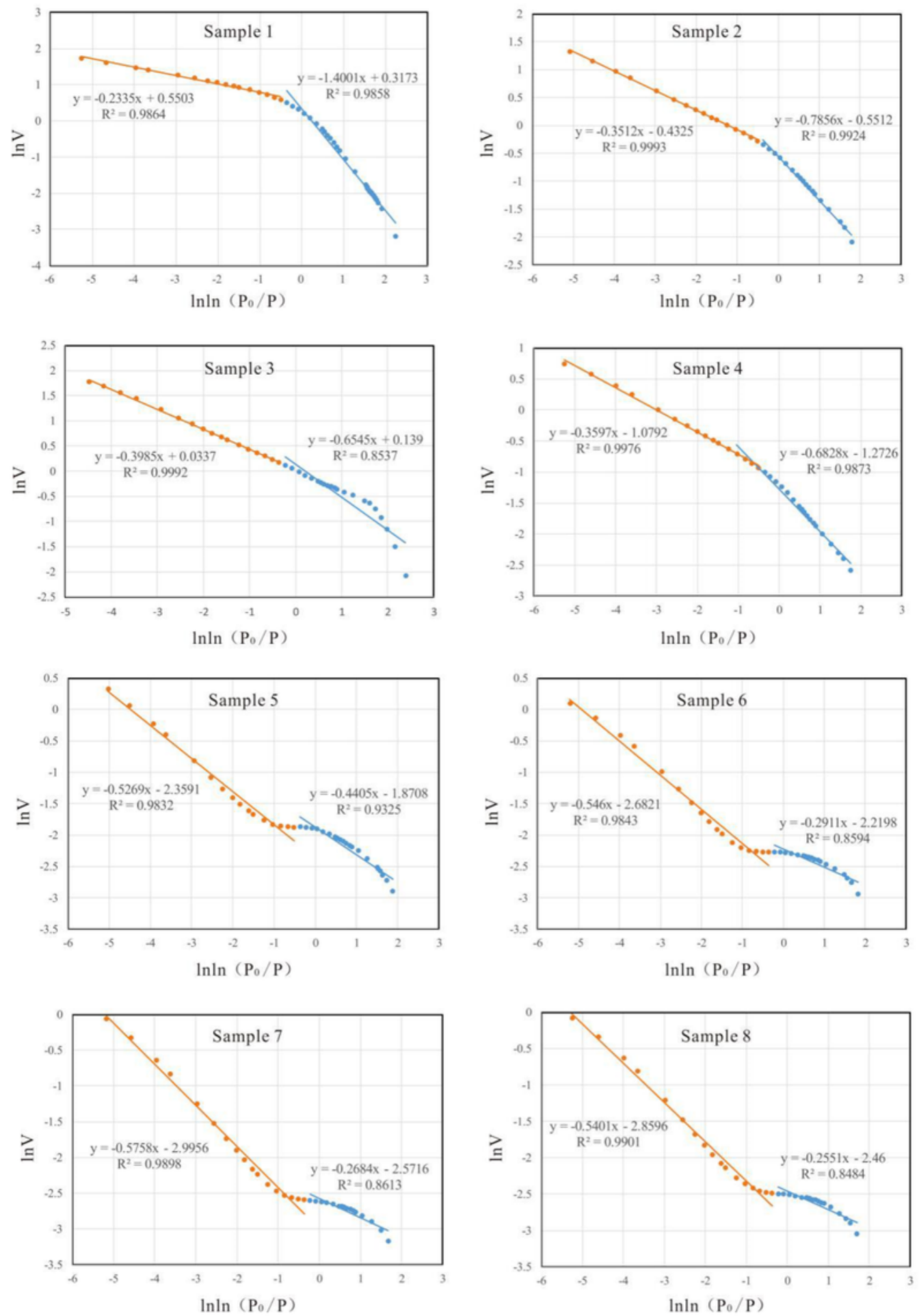

\section{Figure 8}

FHH plots for the metamorphic samples. 

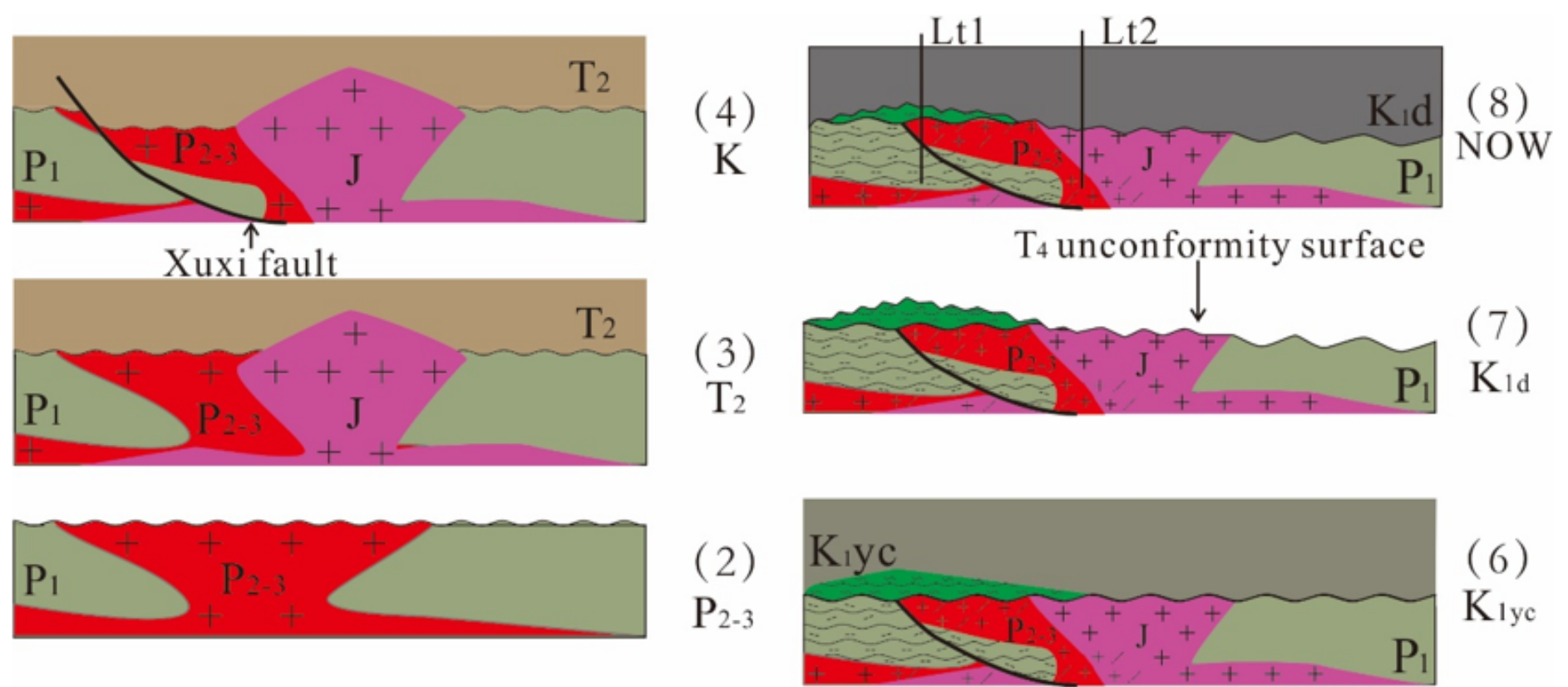
$\mathrm{K}_{1 \mathrm{yc}}$

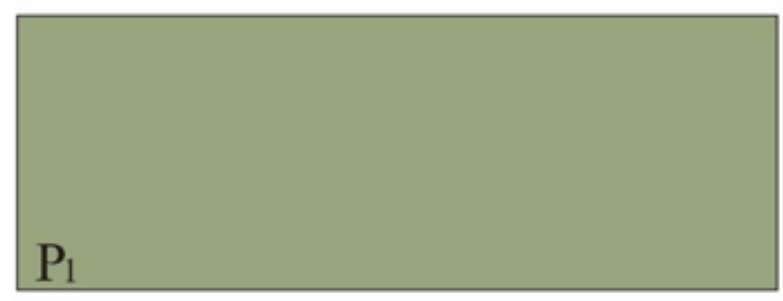

(1) $\mathrm{P}_{1}$

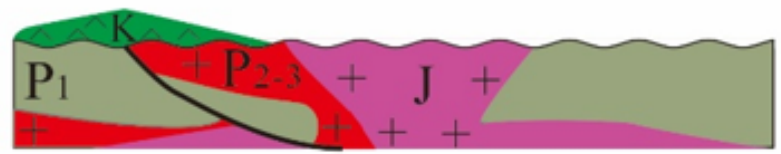

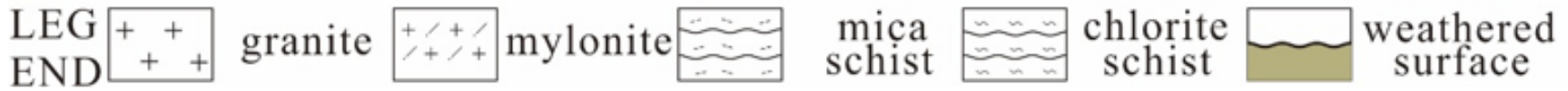

\section{Figure 9}

Inferred formation process of the metamorphic rock reservoir. 